\title{
Confronting clinical challenges and professional stress
}

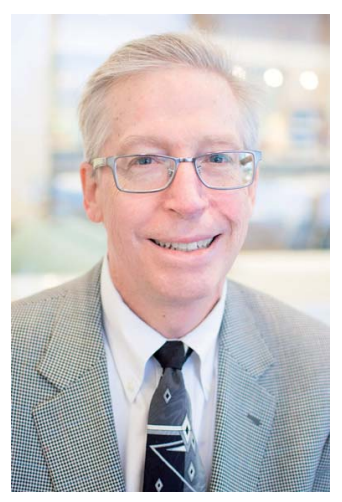

7 his issue of Neurology ${ }^{\circledR}$ Clinical Practice (NCP) features articles that explore challenging clinical scenarios. Karam and Tramontozzi (p. 384) describe rapid

L screening for inflammatory neuropathies, Salter et al. (p. 397) reveal the interactive effects of disability and health behaviors in multiple sclerosis, and O'Connor et al. (p. 419) examine longitudinal behavioral changes in frontotemporal dementia.

In a meta-analysis of hemicraniectomy for severe middle cerebral artery infarction, Streib et al. (p. 433) point out the paradox that this procedure improves both excellent and poor outcomes by improving survival overall. In an accompanying editorial, Neugebauer and Woitzik (p. 381) discuss the nuances of decision-making as they relate to age and level of disability, and the limitations of deriving a single algorithm for treatment options.

Nothing creates more stress in a practicing US physician than a change in Medicare rules and payment options. Jones et al. (p. 459) discuss the passage of the Medicare Access and CHIP Reauthorization Act of 2015 (MACRA), heralding a fundamental shift from volumebased to value-based payment for health care services in the United States. Zuccarelli and Coffman (p. 429) describe a quality improvement project tackling requests for afterhours refilling of prescriptions. In an accompanying editorial, Allison Weathers (p. 379) puts neurologist burnout and the use of quality improvement techniques into greater perspective.

Our Five New Things series provides timely updates on epilepsy by Saipetch et al. (p. 444) and on Parkinson disease and cognitive impairment by Davis and Racette (p. 452).

We strive to make NCP essential reading and welcome your feedback on topics relevant to your practice.

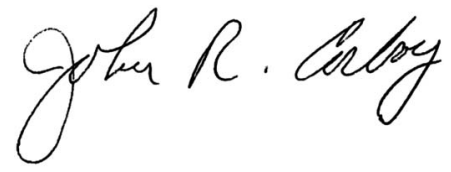

John R. Corboy, MD, FAAN 


\title{
Neurology ${ }^{\circ}$ Clinical Practice
}

\author{
Confronting clinical challenges and professional stress \\ Neurol Clin Pract 2016;6;377 \\ DOI 10.1212/CPJ.0000000000000301
}

This information is current as of October 17, 2016

\author{
Updated Information \& \\ including high resolution figures, can be found at: \\ Services \\ http://cp.neurology.org/content/6/5/377.full.html \\ Permissions \& Licensing \\ Information about reproducing this article in parts (figures,tables) or in \\ its entirety can be found online at: \\ http://cp.neurology.org/misc/about.xhtml\#permissions \\ Reprints \\ Information about ordering reprints can be found online: \\ http://cp.neurology.org/misc/addir.xhtml\#reprintsus
}

Neurol Clin Pract is an official journal of the American Academy of Neurology. Published continuously since 2011, it is now a bimonthly with 6 issues per year. Copyright ( 92016 American Academy of Neurology. All rights reserved. Print ISSN: 2163-0402. Online ISSN: 2163-0933.

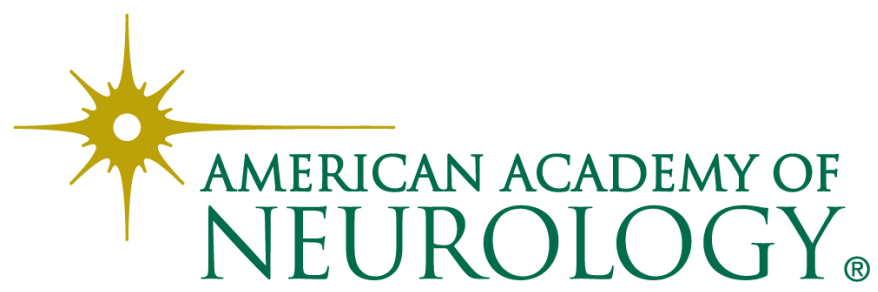

